\author{
Carlo Cristiano* \\ Maria Cristina Marcuzzo** \\ * University of Pisa, **Sapienza, University of Roma
}

\title{
John Maynard Keynes: The Economist as Investor
}

\section{$\underline{\text { Abstract }}$}

Keynes the investor has recently attracted the attention of several scholars and quite a few articles have come out in the last five years. A description of Keynes's dealings has emerged, assessing his performance as an investor as superior but not as stellar as had previously been believed. However, overall evaluation of Keynes's performance is still lacking. This paper contributes to this growing literature by filling some of the gaps, especially in relation to Keynes's investment philosophy and economic theory, and by undertaking a more comprehensive review of the available evidence, drawing on some unpublished sources which have not as yet been fully exploited.

\section{$\underline{1 . \text { Introduction }}$}

The title of the Second Volume of Skidelsky's biography (1983), The Economist as Saviour, conveys the idea of Keynes as both a guardian and a defender of capitalism. There are, however, other aspects to Keynes which suggest a different depiction, or at least a different perspective. Such is the case of his activity as investor and speculator, which was a constant concern throughout his life.

Keynes started up as an occasional investor in the stock market when he was very young. After 1919, thanks to the proceeds of the best-selling The Economic Consequences of the Peace, his dealings grew in magnitude as well as scope. Currency speculation became the main business for a while, leading to a serious loss in 1920, which Keynes had already recuperated by 1922, thanks to the revenues coming from speculation in commodities (metals and cotton) and some still unsystematic forays in securities. Meanwhile, investment had become his main source of income. The data on income by source reported by Moggridge (CWK XII: 12, Table 4) show that commodity speculation took the lion's share during the 1920s - a pattern that probably began to change when Keynes's second major setback came in 1928, and then in the wake of the 1929 crash. Even though Keynes went on trading commodities until the closure of these markets in 1939, early in the 1930s he shifted to equities, his main sources of income being capital gains and dividends. Connected to this is Keynes's exposure on the American stock market, which shows up in the 1920s data and then in 1932-3, before taking on substantial 
proportions as from 1934. Keynes continued to invest until the time of his death in 1946, building up a conspicuous fortune over a period of about a quarter of a century.

Parallel to his personal investment activities, there was an intense career as institutional investor. Keynes became director of the National Mutual Life Insurance Company in 1919, and then chairman in 1921, a post he retained until October 1938. He joined the board of the Provincial Insurance Company in 1923, lessening his involvement in the board only when he joined the Treasury in 1940. Keynes also entered on the Boards of a group of investment trusts founded by O.T. Falk, a former colleague of Keynes at the Treasury. He was a director of the Independent Investment Company (1923-46), the A.D. Investment Trust (1921-27) and the P.R. Finance Company (1924-36, Chairman 1932-36). In addition to these investment companies, there was the Syndicate that Keynes and Falk created for their speculation in foreign exchange, and into which they channelled additional money from friends and relatives (CWK XII: 1, 3-5, 30-5). In 1921, Keynes became Second Bursar of King's College, Cambridge, and then First Bursar in 1924, a post he retained until the end of his life.

Keynes the investor has not been investigated as much as other aspects of his life and work, especially because of the nature of the sources; in his papers there are many files of ledgers, correspondence with brokers, consultants and accounts which are not always easy to decipher and make use of. Moreover, reconstructing the working of the financial markets in the inter wars period would require a full knowledge of data (asset prices, derivatives, commissions, institutional arrangements) which are not always available.

Notwithstanding these difficulties, Keynes the investor has recently attracted the attention of several scholars and quite a few articles have come out in the last five years (Accominotti and Chambers 2014; Boyle, Garlappi, Uppal, and Wang 2012; Cavalli and Cristiano 2012; Chambers and Dimson 2011; Chambers and Dimson 2013; Chambers and Dimson 2015; Chambers, Dimson, and Foo 2015; Cristiano and Naldi 2014; Fantacci, Marcuzzo and Sanfilippo 2010; Foresti and Sanfilippo 2012; Holder and Kent 2011; Marcuzzo 2012; Marcuzzo and Sanfilippo 2015; Wasik 2013; Woods 2013), adding to the hitherto sparse literature on the subject (Davenport 1975, Chua and Woodward 1983a, 1983b; Pierce 1993, Mini 1995), besides of course the editorial notes in Vol XII of Keynes's Collected Writings (Moggridge 1983), which still remain the main and most authoritative reference.

A newer and more reliable description of Keynes's dealings has thus begun to emerge, assessing his performance as an investor as superior but not as stellar as had previously been believed.

Granted that Keynes fared quite well in shares, overall evaluation of Keynes's performance is still lacking. We have partial results, but no complete and detailed analysis has been made of his investments as a whole.

Closer examination of Keynes's dealings in stocks for King's College has shown that in the earlier period of his bursarship Keynes came short of the market performance, and that he did not significantly outperform the market until he changed his strategy in the early 
1930s (Chambers and Dimson 2012). Over the whole period, the annual performance of the funds over which Keynes had complete control amounted to +16.0 per cent, against + 10.5 per cent of the market index (Chambers and Dimson 2013; 2015).

As far as Keynes's dealings in currencies are concerned, Accominotti and Chambers (2014) conclude that Keynes's discretional and fundamentals-based strategy on the whole failed to match the returns to rules-based strategies. Their test included carry trade (which borrows in low interest rate currencies to invest in high interest rate currencies), momentum (which consists in being long on past winners and short on past losers), and value (in which the investor is long on currencies that are undervalued in terms of purchasing power parity and short on overvalued currencies). Keynes only managed to beat the carry trade, but not the momentum strategy, during the 1930s.

On commodity futures and options, Keynes achieved mixed results. During the 1920s, he made some profits in American Cotton (Cristiano and Naldi 2014) and Tin futures (Cavalli-Cristiano 2012), but he also incurred severe losses in rubber (CWK XII: 15), while options gained Keynes a total return on investment of 3 per cent over 12 years of activity. Taking the average yield of Consols as a benchmark, Marcuzzo and Sanfilippo (2015) have shown that this was no great performance: Consols averaged 4.5 per cent during the 1920s and 3.5 per cent in the 1930s.

Moreover, two other aspects of his activity as speculator have undergone scrutiny, namely his investment philosophy and its relationship with his economic theory. While the former has been thoroughly analysed, especially by Wasik (2013) and Woods (2013), we believe there is still more to be done on the latter.

Vol. XII of the Collected Writings contains a long series of public speeches and private correspondence in which Keynes promoted ex ante, or justified ex post, his investment strategy. During the 1930s in particular, the latter case became predominant. As the stock market portfolios of the National Mutual and the Provincial frequently began to incur serious losses, Keynes had to justify his choices. This inevitably led him to produce a considerable flow of letters, memoranda and post mortems on investments, which Moggridge edited in 1983. Together with the more colloquial and relaxed post mortems on King's accounts, also included in vol. XII, these papers remain the main source for most of the contributions on Keynes's investment philosophy (Pierce 1993; Mini 1995; Holder and Kent 2011; Woods 2013).

In this paper we wish to contribute to this growing literature by filling some of the gaps, especially in relation to Keynes's investment philosophy and economic theory. To do so we undertake a more comprehensive review of the available evidence, drawing on some unpublished sources which have not as yet been fully exploited.

\section{Keynes's pronouncements on Institutional and Personal Investment strategies}

Chambers and Dimson (2012: 8) claim that 77 per cent by value (66 per cent by number) of his personal portfolio consisted of shares he bought also for King's. Although 
this can only be a tentative estimate, it seems to corroborate the assumption that Keynes's approach to his private investments often reflected the choices he made also as an institutional investor.

There are, however, limits to the extent to which we can deduce Keynes's personal investment strategy from his institutional investments. One reason is the different time horizon of Keynes the individual investor vis-à-vis the institutional manager. Another is that, King's probably being an exception, Keynes's could not be as autonomous in the management of others' funds as he was in his personal portfolio. Finally, there are two classes of investments that Keynes practised, namely commodities and currencies, which were outside the scope of at least some of his institutional dealings although, as the correspondence with Kahn shows, not in the case of King's as far as commodities were concerned. Currencies and commodities remained outside the portfolios of the National Mutual and the Provincial, however. Nevertheless, the papers and correspondence of Keynes as an institutional investor remain a source of first-hand information.

An early experiment emerging from these papers is to be seen in the "credit cycle" strategy elaborated in collaboration with Falk and explained in the prospectus of the Independent Investment Company of January 1924 (CWK XII: 33). This strategy started from the presupposition that:

"fluctuations in the relative values of ... securities and of ordinary shares are all affected by a periodic credit cycle. Changes in the short-period rate of interest affect the value of long-dated securities to a greater degree that than should strictly be the case, with the result that considerable profits can be made by changing from one class to another at the appropriate phases of the credit cycle. Similar periodic changes also take place in the relative values of money on the one hand and of goods and real property on the other, which are reflected in the relative values of bonds and shares ... so that here also the same principle of changing from one class to another at appropriate times can be applied" (CWK XII: 33). ${ }^{1}$

In the same year of 1924, Keynes was popularizing a new approach to institutional investors called "active investment policy". In an article on "Investment policy for insurance companies” (CWK XII: 240-4), published in May in The Nation and Athenaeum,

\footnotetext{
${ }^{1}$ Much later, Keynes spoke somewhat contemptuously of this strategy. In a letter to Kahn of 5 May 1938 he wrote that he had "seen it tried by five different parties...over a period of nearly twenty years" without "a single case of success" (CWK XII: 100). However, which these "five parties" may be is hard to tell, nor is it clear for how long and how much this strategy was actually followed by Keynes himself. Moreover, as we will see, the cycle investment left some traces also in Keynes's dealings during the 1930s. Nicholas Davenport, who became a member of the National Mutual board in 1932, later recalled: "In the money and bond markets Keynes was able to apply his professional knowledge as an economist and monetary expert. The National Mutual would place its money on 'the street' on a day-to-day basis when some crisis had driven the money rates sharply upward. Then it would move into the government bonds market when it foresaw money rates turning downwards. Finally, it would gather in its capital profits when it considered the gilt edged market had reached its peak. [...] Keynes ... was something to persuade the actuaries of the life offices to keep equities in their portfolios as a fixed and permanent proportion of their assets and to contemplate 'switching' not only when management problems arose but when economic trends pointed to a 'bear' market” (Davenport 1975: 226-27).
} 
he argued that "The wise investor must now doubt all things, and constantly revise his ideas in accordance with changing events in the political world". Subsequently, the annual speeches as President of the National Mutual became the main vehicle for these ideas. The 1928 speech contains a clear definition of active investment policy, borrowed from a report of the Carnegie Corporation. "The funds of a great endowment can be kept intact only by a systematic revision month by month of all securities of the endowment and by a continuous process of sale and exchange as circumstances may affect the financial soundness of this or that security" (CWK XII: 155).

While this "active" policy was put into practice, Keynes grew firmly convinced that it was necessary to reform the portfolios of the companies in which he was involved. The quota of fixed interest securities had to be reduced, and that of equities enlarged. Speaking as President of the National Mutual in January 1928, encouraged by the good results he was achieving, Keynes proudly presented the new approach: "We have been pioneers - he said - in the practice of employing a substantial part of our funds in ordinary shares" (CWK XII: 155). He explained that "the centre of gravity of business, and therefore of investment, is not where it was [before the war]", and that sticking to the orthodox and restricted range of fixed interest securities would mean "living in a backwater". Besides the traditional fields of railways and public utilities, usually within the empire, new opportunities were emerging. He mentioned the oil business, the tea, coffee and rubber industries, and "the ordinary shares of companies overseas, particularly in the United States". In round figures, there were " 250 companies with a total ordinary share market capitalization of about $£ 1,500,000,000 "$, which represented, in Keynes’s view, "the live large-scale business and investment world of today"(CWK XII: 157).

There is no evidence that the crash of 1929 changed Keynes's opinion that investing in equities was the right policy, but it certainly made it much more difficult to make it palatable to the Boards of the National Mutual and the Provincial. From 1930 onwards, the National Mutual speeches showed the need to defend, rather than the will to promote, equity investment. The same happened with the Provincial, as the sample of Keynes's correspondence with F.C. Scott reproduced in CWK XII clearly shows.

The only exception is the management of the funds of King's College.

Throughout a period of about 25 years as Bursar, Keynes enjoyed a privileged position that was largely denied to him as member, or even chairman, of other Boards. In practice, he was given carte blanche in the administration of a considerable amount of money over an indefinite period. This gave him the opportunity to pursue the strategy of investment that best reflected his opinions. While the traditional investment of King's, as well as other colleges, was mainly in real estate and gilt-edged securities, Keynes created and managed for his college a strong position in equities, a policy he tried to maintain also after 1929. Incidentally, the same strategy is still of interest today as a pioneer example of what became customary in College finance only in the second half of the last century (Chambers and Dimson 2015). But in the context of the post-1929 slump, the most salient aspect of Keynes's stock market strategy was his resolution to avoid large liquidation of shares during a period of prolonged and dramatic fall in market prices. This is evident in the 
administration of the King's College funds - Chambers and Dimson place great emphasis on this point - as well as in National Mutual speeches and the published correspondence with other Board members during the 1930s.

However, this trading behaviour was probably the result of Keynes's rethinking at an earlier stage. The earliest evidence of Keynes's preference for equities is the review of Smith (1925), published in May 1925 (now in CWK XII: 247-52). Here Keynes argued that investing in equities was investing in real values instead of money values, and moreover in a world in which money depreciation was supposed to be the most predictable outcome. Another reason Keynes insisted on was that well managed firms do not usually distribute all their profits to shareholders. Rather, they prefer to reinvest this money into business. "Thus there is an element of compound interest operating in favour of a sound industrial investment" (CWK XII: 250). Chambers, Dimson and Foo (2015) have shown how, as time went by, the selection of the most "sound industrial investments", the ones with the best long-term outlook in spite of low current market evaluation, became Keynes's particular hobby in the administration of King's. This entailed that he put relatively large sums of money into relatively few assets, thus betting on his ability to pick out the most undervalued assets while eschewing diversification. Accordingly, the investment policy of Keynes as a mature investor has been described as rather idiosyncratic, and therefore scarcely compatible with collective management.

Turning, now, to his personal investment, at an earlier stage Keynes's personal investments had, as we have seen, been largely in commodities and currencies. In these markets, the kind of "cycle investment strategy" that left traces in Keynes's papers around 1924 was a natural approach. It has been observed (Accominotti and Chambers 2014) that Keynes's exchange speculation "was based on a discretionary analysis of macro-economic fundamentals such as expected changes in official interest rates, the inflation outlook, and the level of European reparations and international capital flows". Moreover, something similar has emerged in closer examination of Keynes's dealings in commodities. There is evidence that Keynes collected detailed information about all the commodities he traded, and that, at least throughout the 1920s, he tried to predict the price trend of each commodity in the context of his broad outlook on the trade cycle. It is even possible that their experience in these markets had some influence on Keynes and Falk when they drafted the Independent prospectus in January 1924, and that they were just trying to extend their experience in commodities and foreign exchange to the bond and share markets.

However, Accominotti and Chambers (2014) note that Keynes also "attempted to exploit information gleaned during his meetings with diplomats, bankers, and stakeholders involved in important currency discussions", which has more to do with the exploitation of specific information advantages rather than with some superior ability in macroeconomic analysis and prediction.

Turning to commodities, we find a similar picture. In his tin dealings Keynes attempted to exploit his personal connections in the City (Cavalli and Cristiano 2012). Moreover, the significant investment in tin shares during the same period in which Keynes accumulated a considerable open interest in this commodity probably depended on the same information. 
Again, Keynes motivated his large investments in South African gold mining shares with his personal exchanges with the manager of a top firm in that business (Henry Strakosch; see Keynes's letter to Scott of 15 August 1934, in CWK XII: 55-7).

As Keynes grew older and his network of personal contacts widened, this kind of strategy became more practicable. In a world void of any serious rule on insider trading, Keynes had no need to hide the fact that he had influential friends in the City. In fact, as so much of the correspondence in the Keynes Papers reveals, in most of the cases this kind of information had nothing to do with inside trading. Rather, Keynes widened his relationship with business houses and professional investors, with whom he could profitably exchange information as well as opinions on a wider range of specific investments.

Along with the "humbling déjà vu of having nearly lost two fortunes" upon which Wasik (2013: 84) places much more emphasis, this could have contributed to making the abandonment of cycle trading quite a natural development, in Keynes's institutional investments as well as in his personal dealings. However, the unpublished material, mainly correspondence, which Keynes held with City people, brokers and friends, has not been fully explored.

\section{$\underline{\text { 3. Keynes's main advisers }}$}

According to a recent study, the network of his "personal contacts from Keynes's time at Eton College, Cambridge University, the Treasury during World War I, and from public life consisted of 7,632 people" (Eldridge 2012, quoted in Chambers Dimson 2013: 225).

Among these myriad contacts, four names stand out - Oswald T. Falk, Rupert Trouton, Walter S. Case, and Richard F. Kahn - while there is a lesser-known one that probably deserves to be added, namely, Francis C. Scott.

Oswald Toynbee 'Foxy' Falk is the man with whom Keynes started up in business on a larger scale. Friends since their days at the Treasury, they cooperated in the creation of a network of financial endeavours in time of peace. After the war, Falk became partner in the stockbroker firm Buckmaster \& Moore, through which Keynes would manage part of his dealings, and preceded Keynes on the Board of the National Mutual. Then, as we have already seen, the two men became co-founders of the Independent, the P.R. Finance Company, the A.D. Investment Trust and the Syndicate. In the mid-1920s they shared the

same enthusiasm for "cycle investment", the idea being that it was possible to make money by predicting economic trends, buying assets when prices were rising and selling them at the beginning of the downturn. The end of their collaboration, if not of their friendship, has recently been attributed to the failure of this strategy and the consequent crisis in which most of their joint endeavours fell with the 1929 crash (Wasik 2013: 70). Another interpretation also gives prominence to their opposed views as to the industrial future of England, and therefore on the advantageousness of investing in the UK market rather than in Wall Street (Millow 2012: 403). A key episode occurred when Falk wrote a letter to the Times newspaper in 1930, urging British investors to fly to the US market as there was no future in London, and Keynes replied to him in turn with a letter to the Times. Keynes 
certainly did so for patriotic reason, and possibly in consideration of his public standing. Whether he actually believed that Falk was wrong is another matter. On the one hand, in the ensuing years he began to invest in Wall Street on a larger scale. On the other, it is also true that he did not abandon the British stock market.

Rupert Trouton worked with Keynes for the Government during the First World War, was his student at Cambridge, and had a lot of dealings with him when he was at Buckmaster and Moore and Laurence, and Keen \& Gardener, which were King's main broker firms. It was Trouton who, in 1921, introduced Keynes to metal options (MarcuzzoSanfilippo 2015). He was a co-founder with Keynes and Falk of the AD Investment Trust, the P.R. Finance Company, where collaboration between Keynes and Trouton was very close. Trouton was able to reverse the fortunes of the company after the bad years 1928-32, and liquidation of the company in 1934 brought profit to the shareholders (Basberg 2015). When Trouton set up his own company, Hector Whaling, in 1928, Keynes remained invested in it, both for himself and for the College throughout its ups and downs to the very end. Trouton, like Kahn was an economist trained by Keynes at King's and their discussions over investment policy must surely have had that particular slant, possibly lacking in other relationships.

Walter Summerhayes Case was an "American investment banker. Founder, 1916, president and director of Case, Pomeroy \& Co., Inc., a private New York investment company with a specialised research organization" (Skidelsky 1992: 690). Since the early 1930s, Case (and his business house) had become Keynes's privileged source of professional analysis and information on specific investments and classes of investments (at least for the US market). This lasted until October 1937, when Case committed suicide. As Keynes put it to Kahn, "It was nothing to do with finance (he had been mainly bearish, particularly in commodities, and was largely out of markets); and I think it was probably due to a recurrence of health trouble which he confided to [Lewis] ${ }^{2}$ (and few others knew I think) ..., but he thought that he had completely recovered" (Keynes to Kahn, 7 October 1937, in Richard Kahn Papers, King's College, RFK/13/57/252-3).

On 22 December 1937, The Times published an obituary of Case by Keynes, now reproduced in the Essays in Biography (CWK X: 326-7). Keynes emphasized Case's view of "the purely financial and Stock Exchange side of his business" as a means to the end of "the active development of the world's resources", his "fanatical enthusiasm for the application of science to business affairs", and the "lavish[ness] in his expenditure on obtaining the best possible assistance and advice" (CWK X: 326). Unfortunately, Keynes also had to remark that Case "never wrote a letter or put a pen to paper" and that "he was addicted to the long-distance telephone even beyond ordinary American usage". Despite Keynes's dislike for telephone conversation, ${ }^{3}$ this did not prevent Case from becoming "The American Financer with whom I was most intimate and on whose advice I most

\footnotetext{
${ }^{2}$ Probably Sir Alfred Edward Lewis, director of the National Provincial Bank and member of the Economic Advisory Council (Moggridge 1992: 888).

${ }^{3}$ See J.M. Keynes, The nuisance of a telephone. To the editor of the New Statesman, 23 December 1922 in CWK XVIII: $100-1$.
} 
relied" (KP BM/3/51), as Keynes wrote to Francis C. Scott on 25 April 1939. A few weeks before Case's death, Keynes reported to Kahn that, "In light of his [Case's] opinion, he had just ordered "for myself and the College" "some more" of "Homestakes". The same letter includes some examples of the kind of information that Keynes received from his friend and the use he made of it:

"U. S. Smelting5. He remains of the same opinion, though he is annoyed that apparently there is not as yet any material increase in the output of lead. The stickiness of the price is due, he says, to selling by a large estate, which has to realise the money, and puts stock on the market whenever the price crosses 90 .

[...] United Gas and Electric Power and Light. He had no information about the arrangements for financing, but he is confident that they are not yet at an end of their important oil-field discoveries. They have a major field in the Rodessa and a minor field in the Sligo, but they will be extremely unlucky if they do not find at least one more major field, and they might do better still. I enclose a cutting from the Financial News, in case you have not seen it. Generally speaking he was just as keen on Utilities as we are (Keynes to Kahn, August 1937, in RFK/13/57/213-6).

Richard Kahn was, as we know, Keynes's "favourite pupil", a companion travelling with him on the road towards the General Theory, and a friend and collaborator of Keynes's in several academic, personal and financial matters; in his capacity as Second Bursar of King's and Director of the Tilton Company, he assisted Keynes in several investment decisions and shared with him assessment of market conditions, upon which they acted both for their own portfolio and for the College. So much is testified by the correspondence between the two, consisting of 611 letters, only 68 of which were published in the CWK (Marcuzzo 2005). Almost half of the surviving letters are from 1937 and 1938, as from the time when Keynes had fallen seriously ill in the Spring of 1937 and for months all financial and academic matters were handed over to Kahn (see Fantacci, Marcuzzo and Sanfilippo 2010).

What these letters tell us is that on each issue they exchanged detailed information, comparing their respective evaluations and assessments, on commodities, American and British shares, bonds and currencies. Keynes taught Kahn - who was in any case by nature so inclined - to keep updated with detailed knowledge of every aspect of the matter in hand. On the other hand, he was also giving Kahn tips based on his wisdom as investor, as the following excerpts illustrate:

“..as you are discovering, [dealing in commodities] it is a business which needs hard work; and it does not turn out right over a period of years unless one attends to the details which, cumulatively, add up to quite a lot. But it is a pure game and should not use time available for serious tasks" (Keynes to Kahn, 14 July 1937, RFK/13/57/193-4]

\footnotetext{
${ }^{4}$ Homestake Mining Company, owner of a gold mine in Dakota, was listed in the New York Stock Exchange ${ }^{5}$ United States Smelting Refining \& Mining Co. http://www.ahgp.org/inter-mt/united-states-smelting-refining-mining-company.html
} 
"For several years I have always felt during a recession that it was worth hanging on, and, provided one's cover position was all right, all one had to do was to wait; so that if I felt the cover position was quite safe, I didn't bother. But today I don't feel like that. I don't want to have a big loan, even though the cover position is perfectly good. I've not got to the point of being a bear, but I am much more disinclined to be a bull on borrowed money" (Keynes to Kahn, 2 September 1937, RFK/13/57/231-2, in CWK XII: 24-5).

The correspondence with Francis Clayton Scott is also very revealing in similar respects. Scott was born in 1881 and educated at Bedales and Oriel College, Oxford (Moggridge 1992: 902). In his capacity as President of the Provincial Insurance Company, he was in constant touch with Keynes. The sample of this correspondence that is reproduced in Vol. XII of the CWK suggests that the two men disagreed on investment policy, Scott being more sensitive than Keynes to short-period fluctuations of asset prices.

However, the relationship with Keynes was much more friendly, and their correspondence more constructive, than the published material would suggest. Part of this correspondence will be considered in the next section, together with other evidence mainly unpublished, drawn from the Keynes Papers - that can add something to our understanding of the developments in Keynes's thinking.

\section{Developments and Change in Keynes's Investment Philosophy Reconsidered}

There is general agreement in the recent literature that the turning point in Keynes's stock market investments came with one major change that occurred in the early 1930s. It is a well-established fact that, by this time, Keynes had decidedly shifted to the kind of buy-and-hold approach that is well exemplified in his college administration, and that Keynes based this strategy on limited diversification and a highly idiosyncratic selection of a restricted set of shares. Also Marcuzzo and Sanfilippo (2015) found that Keynes basically gave up his dealings in options in the early 1930s, which can also be interpreted as a break in his style of investment.

Less clear is why, and exactly when, Keynes changed his mind, and how the new stock market strategy relates to the parallel investment in commodity and exchange markets. Of course, this is not something that can be divined from Keynes's utterances, however numerous they may have been. Without all-inclusive study of Keynes's portfolio and its evolution, no final conclusion can be reached on this matter. One point we might venture at the present stage is that the distinction between the two strategies was probably more blurred than is sometimes suggested.

For instance, a letter from Falk to T. J. Carlyle Gifford (co-director at the Independent Investment Company) sheds some light on how the cycle investment strategy may have been carried out in practice. The letter was sent on 8 February $1924 .{ }^{6}$ Falk explained his

\footnotetext{
${ }^{6}$ A copy of this letter was forwarded to Keynes, among whose papers it remained (see KP IIC/1/1-5).
} 
dislike of an operation that the two were considering. What this investment was is not clear, but Falk did not like it for two reasons. First, he found it "too great a departure from the credit cycle plan". Second, the proposed purchase was too small. Falk's argument was that their policy at the time was to invest a certain amount of money in a limited number of assets. Otherwise, they would have had to "acquire information" on too many assets. This seems to suggest that, even at the beginning of the cycle trading period, the strategy was not altogether top-down but at least in part bottom-up.

Evidence and common sense concur in suggesting that Keynes never dropped his own view on general business trends just because he had abandoned cycle trading. By the time he had switched to the bottom-up approach, Keynes's opinions as a professional economist were purchased (at no trifling cost) by business houses which employed them as a basis for their investments. There is no reason to suppose that he failed to employ the same analyses in determining his own investments and those of the Provincial, King's and so on. Moreover, Keynes's correspondence with Scott shows that predictions about the cycle continued to find a place in Keynes's reasoning:

"As regards buying some more railway shares, I personally entirely agree with you. Indeed, I am rather strongly in favour of them. They seem to me to be an almost ideal credit cycle security, in the sense of being good things to buy when one hopes it is somewhere near the bottom of the slump" (Keynes to Scott, 19 August, 1932; KP $\mathrm{PC} / 1 / 1 / 130)$.

What Keynes added along the way was a huge amount of detailed information on a selection of shares from a number of sources, along with an ever more refined taste (developed by cross-examination as well as trial and error) for these sources of professional (as distinguished from confidential) information and business analysis.

On 10 October 1935, for instance, Keynes wrote a letter to Scott containing four pages of detailed analysis of Austin Motors from both the industrial and financial points of view. This is only one example of Keynes's detailed study of one of his "pets", but an entire paper could be dedicated to his long disquisitions with Scott on Austin Motors shares and a few other equities.

As mentioned above, Scott was not as inclined as Keynes to eschew the speculative mentality. Nevertheless, their dialogue always remained on a constructive basis, apparently because Scott adhered to the same idea of "active investment policy" supported by Keynes. This emerges in all evidence on perusing not only the letters but also the accompanying material and the related correspondence, as now collected in the Keynes Papers. The bulk of this material amounts to hundreds of documents of a sundry nature, but all relate to the same need, which was to keep up to date with the markets by constantly gathering evidence.

In this respect, the correspondence with Scott sheds light on a revealing though lesserknown aspect of Keynes's business relationship with Walter Case. When D.S. Roswell, a former employee of Case, Pomeroy and Co was about to set up a new business firm after Case's death, Keynes wrote to Scott about the proposed collaboration, describing Roswell 
as Case's "principal expert in reporting on the intrinsic value and prospects of American companies". He told Scott he had known Roswell "for a long time past", and that "he had more faith in his opinion ... than anyone else I know", but also that, unless Keynes could meet Roswell during one of his American visits, this opinion was usually filtered through Case. Now Roswell was "prepared to offer his services to a limited clientele" for an annual fee of $£ 2,500$ which, Keynes proposed, could be divided between the Provincial, King's College and himself. ${ }^{7}$

A passage in Keynes's letter to Scott is particularly revealing of the kind of information that Keynes was looking for as a mature investor at the apex of his career:

"What he does is to make incredibly careful studies of the intrinsic value and long period prospects of the main American securities, the sort of study which it is unfortunately impossible to have made in this country for lack of data, but which can be made in America, especially in the case of the leading utilities" (Keynes to Scott, 25 April 1939; KP BM/3/158).

No doubt this is further proof that Keynes's investment philosophy had definitely turned against cycle investment and in favour of stock-picking value investment. In the context of the correspondence with Scott, however, another interesting possibility this passage suggests is that Keynes was looking for a kind of business information and analysis that could be complementary to his own information and analysis as an economist. Connected to this is the fact that the choice between different markets sometimes depended on the relative costs and availability of information, Wall Street being at an advantage over London in this respect.

Taking a broader view, what emerges from Keynes's relationships with his major advisers is that his individualism as an investor may have been somewhat exaggerated. Keynes is frequently quoted for his observation that "It is astonishing what foolish things one can temporarily believe if one thinks too long alone, especially in economics" (Preface to the General Theory, CWK VII: xxiii). Apparently, for Keynes the same applied to business, too.

True enough, Keynes sometimes complained of the advice received from his correspondents. ${ }^{8}$ On the whole, however, Keynes relied on them. In the same vein, the fact that he sometimes expressed dislike for Board management may have concealed another fact, namely that he did like to have frequent exchanges of information and qualified opinions with a select range of friends and collaborators. What the Keynes Papers abundantly show is that for Keynes investment was a time-consuming activity in which building up a network of reliable connections and collecting sound, relevant information was a costly but decisive task. This he made quite clear in a letter to Scott:

\footnotetext{
${ }^{7}$ In the end a deal was reached, as Keynes announced to Roswell on 10 May (KP BM/3/171).

${ }^{8}$ As, for example, in the following excerpt about the losses incurred by the National Mutual: "You will notice that these are practically all specialties and rather obscure concerns, mostly bought on private advice. Omes was due to Trouton: Carbo Plaster and South African Torbanite to Falk; Enfield Rolling Mills and Grand Union Canal to [W. Harold] Brett. I am sure experience shows that private and personal recommendations of this class of security tend to turn out wrong in the long run" (JMK to F. C. Scott 7 June 1938; in CWK XII: 56-6). W.H. Brett was one of the brokers employed by the Provincial.
} 
"It sometimes seems to me that apart from the noble army of investors who never read the newspapers I am almost the only person left who has an investment rather than a speculative mentality! On every Board I sit on the great majority are influenced far more by the daily fluctuations which they read of in the newspapers than by reasoned calculation of yield or ultimate prospects" (Keynes to Scott, 7 June 1937; KP PC/1/4/306).

Given this approach, Keynes reaped considerable economies of scale through his participation in several Boards, which might explain why he stayed on them even though he was wont to say that he could not stand them:

"The danger of Board management, against which one has to be on one's guard, is lest one should succeed in persuading the Board rather against its better judgment in the first instance, and then have to suffer the penalty of their faint-heartedness at a later date, just when the virtues of continuity of mind are most required if one is to be successful in the long run" (Keynes to F.C. Scott, 29 November 1933; in CWK XII: 65).

Connected to this is the extent and variety of information that could be relevant for a man who was a professional economist but not a full time business man (like, for instance, Case). This is especially true of the 1930s. As an investor, Keynes had now grown up from the amateurish style of the early 1920s, when Trouton and Falk had to brief him on cotton futures or metal options. But he was also engaged in a considerable number of parallel activities as an economist.

As it turns out, Keynes's portfolio choices may have been the result of the juxtaposition of his general vision and systematic analysis of the entire economic system with the information he could actually obtain - this latter element being, at least to some extent, more a matter of circumstances than of deliberate choice. The evolution of Keynes's economic thinking ran parallel to the development of his business skills, the increase in his business contacts, and a process of selection of these sources of information.

\section{The investor as economist and the economist as investor}

It is more than likely that there was some connection between Keynes's changing investment policy and the developments in his economic theory. His views on speculation changed over the years as his theory developed and his practice as speculator improved.

The first instance was in 1910, when he was a lecturer at Cambridge and had practically no experience in the Stock Exchange. In his lectures Keynes distinguished between speculators, who base their decision on the possession of "superior knowledge", and gamblers, who just take more or less calculable risks, as in the game of roulette. Superior knowledge confers the speculator with an advantage over the market. To Keynes this is a matter relevant not to measuring comparative success in gambling and in speculation, which may be dependent on other factors, but to evaluating the nature of the action in the two cases. Unlike speculation, gambling is not reasonable because it is a behaviour which has no basis in knowledge, notwithstanding the fact that a gambler may at times be a winner and a speculator a loser (see KP/UA/6/3 and Carabelli 1998). 
The next phase in Keynes's thinking - as he became more closely acquainted with the working of markets-was the analysis of speculation in futures (currencies and commodities) presented in his 'The Forward Market in Foreign Exchanges' (1922), incorporated in the Tract of Monetary Reform (1924) and in his 1923 article 'Some Aspects of Commodity Markets' (CWK XII: 255-65). The points made there were reiterated in the Treatise on Money, where he gave a more refined version of his theory.

Futures contracts are described as a form of insurance policy against price fluctuations. By stipulating these contracts, producers (consumers) of a commodity for which a future market exists fix in advance the price of a future sale (purchase), thereby freeing themselves from the risk of a price decrease (increase). Keynes assumes that it is mostly professional speculators, generally less risk averse than producers, who make forward purchases. The prospect of gaining from price changes by buying forward in anticipation of a price increase would eventually allow speculators to resell at a profit on maturity of the forward contract (Fantacci-Marcuzzo-Sanfilippo 2010).

Speculators who enter into forward contracts do not have firm expectations of price changes, and hence of windfall profits, but, by providing an insurance against unexpected price changes, they enter the market for the gain they stand to make, rewarding them for the risk price changes entail. Thus, in Keynes's new view, the speculator's ability to forecast the future through superior knowledge is downplayed. He is not "a prophet" (CWK XII: 260), i.e. someone who can anticipate price movements more accurately than other actors, but rather a "risk bearer" (CWK XII: 260).

This new view did not rule out the importance for a speculator of being acquainted with the working of the future markets, nor of being knowledgeable about specific commodities or currencies, on which the dividing line between a gambler and a professional trader is drawn. In fact, in the transition between the Treatise and the General Theory, the original idea of rational speculation based on knowledge was incorporated into other terms, like "investment" or "enterprise".

As Keynes became more and more an investor in shares, rather than a speculator in commodities - sometime during the period 1933-34, which also saw his "revolution" in economic theory in progress - his views on speculation extended to the idea of conformative behaviour based on some tacitly established convention. "For a speculator is a man who anticipates the behaviours of other speculators, so that if all speculators have the same anticipations, all of them will, temporarily, be right; and only when the music stops - for musical chairs is the game which speculators play with one another - will someone find himself without a seat" ("The Kaffir Boom" February 1933; in CWK XXI: 227-8). ${ }^{9}$

\footnotetext{
9 "Kaffirs" was the name given to the South African gold shares quoted on the London market. When South Africa abandoned the gold standard in December 1932, the South African pound depreciated, thus boosting the local currency receipts of the South African gold mining companies. This led to a boom in "Kaffirs" in London.
} 
This is the view of speculation that found definitive exposition in chapter 12 of the General Theory, which hinged upon the opposition between speculation as the attempt to adapt to other's people opinions - no matter whether right or wrong - and enterprise as a behaviour based on actual knowledge of fundamentals.

This entailed transition from a view of speculation as a form of rational and socially sound economic behaviour, most plausibly rooted in the cross fertilization between the Marshallian explanation of the subject and Keynes's own ideas on rationality, to a view of speculation as possibly rational from the individual agent's viewpoint, but antisocial. As Dardi and Gallegati (1992: 582-3) argue, the view of speculation as distinguished from enterprise, and the distinction between the professional speculator and the amateur, are common to Keynes and his master. Unlike Marshall, however, Keynes grew convinced that the information advantage of the speculator (relative to the amateur) was not about fundamentals. If any advantage there was, it was about the average opinion of the market.

Viewed from the standpoint of his investments, which was so very fundamentalsoriented, speculation may have become for Keynes not just an alternative to, but also an obstacle in the way of, sound investment, or enterprise.

\section{Conclusions}

In this paper we have reviewed the growing literature that has in recent years taken up a somewhat neglected aspect of Keynes's life as speculator and investor. In particular, we have pieced together the evidence collected on his performance, pointing out that much more needs to be researched before we can conclude that it was in fact "stellar", as the traditional account has it.

As far as his investment philosophy is concerned, there seems to be a general consensus in describing it as characterized by two distinct phases: the first, from the early 1920s to the early 1930s, guided by the "credit cycle" approach; the second, which Keynes then turned to and pursued to the end, a bottom-up strategy. Cycle trading assumed that assets in general are systematically under- or overvalued at different stages of the trade cycle, and that decisions to sell or purchase should therefore be based more on general conditions than on specific knowledge of individual assets and their fundamentals. By contrast, the second approach assumes that with closer examination of specific assets and their fundamentals it is possible to pick out the best of them in terms of prospective yield and/or current price.

While we agree that there seems to be a clear break in his investment behaviour, we would hesitate to attribute it to complete abandonment of the credit cycle approach; indeed, we believe he never completely relinquished it, even during the years when he focused on picking the shares which promised well in terms of future yields.

On the basis of some unpublished material, in particular the correspondence with Scott, we have, we hope, helped to fill in the picture of how Keynes's formed his opinions, what information he was seeking and on whose advice he relied mostly. In addressing the 
evolution of his trading behaviour, we have tried to match it with the developments in his economic thinking in general and on speculation in particular.

What emerges from all this is that Keynes never ceased to be first and foremost an economist who never lost sight of the complexity of factors behind the surface of price changes; while he progressively lost confidence in the ability to predict their course in the short run, he remained confident that study of the fundamentals of the economy and of what underlies the individual asset would provide a reasonable basis for rational, and in the long run at least, successful choice.

\section{$\underline{\text { References }}$}

Accominotti, O. and Chambers, D. (2014) 'The returns to currency speculation: Evidence from Keynes the trader', Vox, Vol. 18, pp. 1-5

Basberg, B. (2015) Keynes, Trouton and the Hector Whaling Company. A personal and professional relationship, Working Paper n.8, Norwegian School of Economics

Boyle, P., Garlappi, G., Uppal R. and Wang T. (2012) Keynes Meets Markowitz: The Trade-off between Familiarity and Diversification, Management Science 58 n. 2, pp. $253-$ 72.

Carabelli, A.M. 1998. "Alcune osservazioni sulle Note di Keynes del 1910 sulla speculazione". In A. Vercelli (ed), Incertezza, razionalità e decisioni economiche. Bologna: Il Mulino, pp. 207-22.

Cavalli, N. and Cristiano, C. (2012) 'Keynes's speculation in the London tin market: 1921-1930', in Marcuzzo, M.C. (ed), Speculation and regulation in commodity markets: The Keynesian approach in theory and practice, Rapporto Tecnico, n. 21, pp. 57-78.

Chambers, D. and Dimson, E. (2011) Keynes the stock market investor, SSRNid2023011.

Chambers, D. and Dimson, E. (2013) "John Maynard Keynes, Investment Innovator." Journal of Economic Perspectives, Vol. 27, no. 3, pp. 213-228.

Chambers, D. and Dimson, E. (2015) The British Origins of the US Endowment Model, Financial Analysts Journal, Vol. 71, n. 2, pp. 10-14

Chambers, D., E. Dimson, and J. Foo (2015) 'Keynes, King's and Endowment Asset Management." in How the Financial Crisis and Great Recession Affected Higher Education. Edited by J. Brown and C. Hoxby. Chicago: University of Chicago Press, pp. 127-50.

Chua, J. H. and Woodward R. S. (1983a), The Investment Wizardry of J. M. Keynes, Financial Analysts Journal, Vol. 39, n. 3; pp. 35-37.

Chua, J. H. and Woodward R. S. (1983b), J. M. Keynes's Investment Performance: A Note, The Journal of Finance, Vol. 38, no. 1, pp. 232-235 
Cristiano, C. and Naldi, N. (2014) 'Keynes's activity on the cotton market and the theory of the "normal backwardation”: 1921-29', European Journal for the History of Economic Thought, vol. 21, n.6, pp. 1039-1059.

Davenport, N. (1975) 'Keynes and the City', in M. Keynes, Essays on John Maynard Keynes, Cambridge: Cambridge University Press, pp. 224-29.

Eldridge, M. (2012), Keynes' Personal Investor Network. Cambridge University MPhil Dissertation.

Fantacci, L., Marcuzzo, M.C. and Sanfilippo, E. (2010) 'Speculation in Commodities: Keynes' "Practical Acquaintance" with Future Markets', Journal for the History of Economic Thought, Vol. 32, n. 3, pp. 397-418.

Fantacci, L., Marcuzzo, M.C., Rosselli, A., and Sanfilippo, E. (2012) 'Speculation and Buffer Stocks: The Legacy of Keynes and Kahn', The European Journal of the History of Economic Thought, Vol. 19, n.3, pp. 453-73.

Foresti, T. and Sanfilippo, E. (2012) 'An analysis of Keynes's investments in the wheat futures markets: 1925-1935”, in Marcuzzo, M.C. (ed.), Speculation and regulation in commodity markets: The Keynesian approach in theory and practice, Rapporto Tecnico, $\mathrm{n}$. 21, pp. 79-105.

Holder, M.E. and Kent, R.J. (2011) 'On the Art of Investing According to Keynes', The Journal of Portfolio Investment, Spring 2011, pp. 1-6.

Keynes, J.M. (1971-1989) The Collected Writings of John Maynard Keynes (CWK), Managing Editors E.A.G. Robinson and D. Moggridge, London: Macmillan.

CWK VII The General Theory of Employment, Interest and Money.

CWK X Essays in Biography.

CWK XII Economic Articles and Correspondence, Investment and Editorial.

CWK XVIII Activities 1922-1932. The end of reparations

CWK XXI Activities 1931-1939. World Crises and Policies in Britain and America.

Marcuzzo, M.C. (2005) Keynes and his favourite pupil. The correspondence between Keynes and Kahn, in M.C. Marcuzzo and A. Rosselli (eds), Economists in Cambridge. A study through their correspondence, 1907-1946, London: Routledge, pp. 21-57.

Marcuzzo, M.C. (2012) 'From speculation to regulation: Keynes and primary commodity markets', in Marcuzzo, M.C. (ed.), Speculation and regulation in commodity markets: The Keynesian approach in theory and practice, Rapporto Tecnico, n.21, Dipartimento di Scienze Statistiche, Sapienza, Università di Roma, pp. 3-23.

Marcuzzo, M.C.-Sanfilippo E. (2015) 'Keynes and the Interwar Commodity Option Market', Cambridge Journal of Economics, forthcoming.

Millow, A (2012) Osward T Falk: Keynes's model economist, Journal of the History of Economic Thought, Vol. 34, n. 3, pp. 397-410. 
Mini, P. V. (1995) 'Keynes' Investments: Their Relation to the General Theory', American Journal of Economics and Sociology, Vol. 54, n.1, pp. 47-56.

Moggridge, D. E. (1983) 'Keynes as an investor', Editorial Introduction to the Vol. XII, Economic Articles and Correspondence, Investment and Editorial, in The Collected Writings of John Maynard Keynes, London, Macmillan, pp. 1-113.

Pierce, T. (1993), Keynes' personal investing: Activities and beliefs, Social Science Journal, Vol. 30 n. 1, pp. 13-22.

Smith, E. L. (1925) Common Stocks as Long Term Investments, New York and London: Macmillan.

Wasik J. (2013), Keynes's Way to Wealth: Timeless Investment Lessons from The Great Economist. McGraw Hill.

Woods, J. E. (2013) On Keynes as an investor, Cambridge Journal of Economics, Vol. 37, n. 2, pp. 423-42 